\title{
Haemophilia, blood transfusion, and the AIDS virus
}

After the near hysterical publicity given to haemophiliacs who have antibodies to the acquired immune deficiency syndrome (AIDS) virus, anyone might be forgiven for supposing that childhood exposure to human $\mathrm{T}$ cell lymphotropic virus (lymphadenopathy associated virus) (HTLV III (LAV)) is confined to patients receiving blood or blood products. This is of course not so, and in the United States the great majority of seropositive children have acquired the virus from their infected mothers during the perinatal period. ${ }^{1}$ As the AIDS experience of the United Kingdom seems to be following that of the United States with about a three year time lag, the same may be true here by 1987 .

The reason that haemophiliacs have so far occupied centre stage is twofold-they were the first group of UK children to be exposed to HTLV III by way of imported factor VIII concentrate, and they form a small, well defined population that happened already to be under close medical surveillance. By fortuitously becoming an ideal pilot group for study, they have also unfortunately become the focus for a great deal of publicity and inflated debate involving moral, ethical, and even philosophical issues, which have rather tended to obscure the size and actual nature of the medical problems involved. There is a touch of irony about this in that the fuss is reaching a climax at a time when the incidence (as opposed to the prevalence) of transfusion transmitted HTLV III infection has hopefully dwindled to zero. Large pool blood products are now nearly all processed in some way to remove or inactivate the virus, and blood donations in the UK are being tested for anti-HTLV III before being issued. Nonetheless, before such precautions were introduced, boys with haemophilia did become infected, and this annotation is an attempt to reflect on how many there are and the problems they present both to themselves and their contacts. In addition, there may be a tiny number of UK children infected by blood products given for reasons other than haemophilia or allied disorders. What follows is equally relevant to them.

\section{The prevalence of transfusion transmitted HTLV III} infection

According to the Haemophilia Centre Directors' annual returns, it seems that there are presently around 900 boys aged under 15 in the UK with classical haemophilia. The proportion of them who have antibodies to HTLV III is not known for certain, but on data currently available the total is tentatively estimated to be around $170(19 \%)$. Such an overall figure has to be immediately qualified, however, as it is influenced by three important factors. Firstly, it varies considerably in different parts of the country according to the type of factor VIII replacement therapy given. The highest numbers are being seen where large pool factor VIII concentrate from several sources has been used and the lowest where only cryoprecipitate from single donors or concentrate made by the UK transfusion service has been given. Secondly, it varies according to age, with those aged under 5 showing a lower seroconversion rate than the 10-14 year olds. Thirdly, it varies with disease severity, with those most severely affected having a higher seroconversion rate than the more mildly afflicted patients. All three factors may merely relate to the amount of antigenic exposure experienced.

The figure also has to be qualified by saying that the final total will probably be higher, partly because the estimate is an extrapolation from incomplete data, and partly because, although virus transmission by transfusion had more or less ceased by the time the survey was done on which it is based, not all exposed individuals would have necessarily seroconverted by then. Under experimental conditions the time from exposure to seroconversion in chimpanzees is thought to be around 10-12 weeks, ${ }^{2}$ but humans, receiving a smaller inoculum, may well take longer.

For the 200 British boys with Christmas disease the seroconversion rate so far seems to be much lower-less than $2 \%$. The main reason for this is presumably that little imported factor IX concentrate has been used in such patients, who have mostly only received material from UK volunteer donors.

The consequences of transfusion transmitted HTLV III infection

The proportion of individuals exposed to HTLV III 
who will never show any overt symptoms of infection is not yet clear, but in haemophiliacs it seems to be large, over $80 \%$, with positive serology being the only legacy of exposure long past the median incubation period of AIDS. ${ }^{3}$ As antibodies to HTLV III are non-neutralising, long term virus carriage is also assumed to occur in such patients, so for the present they are regarded as potentially infective.

For the less fortunate few a number of other unpleasant sequelae might arise, and several syndromes other than frank AIDS follow HTLV III infection. Some are acute, occur shortly after exposure, and include a glandular fever like syndrome and an encephalitis, but more commonly HTLV III associated disease is chronic, producing lymphadenopathy, weight loss, night sweats, and thrombocytopenia, forming, with associated lymphocyte abnormalities, the so called AIDS related complex (ARC). Up to the autumn of 1985 no UK children with haemophilia were reported to have developed frank AIDS, though a few had developed other HTLV III associated disease, and based on adult experience it is probable that some will, in time, develop opportunistic infections.

\section{The risks associated with HTLV III infected children}

The risks associated with HTLV III infection can be considered in two categories: those encountered by the infected child and those experienced by his contacts.

Risks to the infected child centre around potential immunodeficiency and susceptibility to opportunistic or overwhelming infection. There may be a case for passive immunisation after exposure to chickenpox or measles, and live vaccines should also be avoided, but the benefits of attending school far outweigh the risks, and no seropositive children should be kept at home for their own protection.

As for risks to contacts, it is here that a sense of perspective is hardest to achieve. Based on present evidence the risks of casual transmission of HTLV III by young children to playmates at school or at home seems to be negligible. At the time of writing not a single documented case of HTLV III infection had apparently been acquired in such a way, either in the UK or the USA. Similarly, several studies on families with HTLV III seropositive members had all failed to show virus transmission between members unequivocally arising outside the context of sexual or perinatal transmission. ${ }^{4}$

Given such low risks, do any precautions need to be taken with the child who is positive for HTLV III? This question is often asked by teachers, family members, nurses, health visitors, and social workers, not to mention community paediatricians, school medical officers, general practitioners, and dentists. It is tempting to say no, but it is hard to give an unequivocal answer. As HTLV III is present in blood, saliva, and tears, it could be argued that anybody exposed to such substances from an infected boy is theoretically at risk. Government guidelines are somewhat confusing because those given to hospitals and laboratories handling samples from HTLV III positive patients suggest the use of gloves, gowns, and eye protection, whereas those given to seropositive individuals at home inconsistently recommend only that toothbrushes or other implements that could become contaminated with blood should not be shared and that accidents involving blood spillage should simply be cleaned with household bleach. ${ }^{5}$

Where does common sense end and panic begin? It must be stressed again that HTLV III is only known to be transmitted sexually, perinatally, or by direct inoculation. It is because of the latter risk that hospital personnel are advised to take such elaborate precautions, though many experts privately admit that provided good medical techniques are practiced on all patients the HTLV III carrier poses no special threat.

On balance it seems that all that is required on the domestic and social front is attention to good hygiene, and certainly no attempt to isolate seropositive children is justified. If so, another difficult question arises-who needs to know that a given boy is seropositive? Again the answer is not simple, partly because of the circumstances pertaining to adult non-haemophilic seropositive individuals, where confidentiality has to be maintained under the 1974 National Health Service Venereal Disease Regulations, and partly because of the lay public response to the discovery that boys are seropositive, which tends to make them latter day lepers.

To avoid unnecessary distress, at present most haemophilia centre directors confide information about the HTLV III state of their patients to others strictly on a 'need to know' basis, tailoring the dissemination of information to the individual patient. This would usually (though not always) include the general practitioner and usually (though not always) exclude the headmaster. It would invariably include the parents, together with a lengthy explanation of what the finding means, what it does not mean, and who in turn should be told by them if the need arises, such as dentists or staff at haemophilia centres other than the patient's own. Older boys would need to be told themselves, particularly if the question of sexual activity is relevant. For them the risk of disease transmission 
is real and detailed advice on sexual behaviour is required.

\section{Conclusion}

In such an emotionally charged area it is probably helpful to hang on to facts rather than feelings, and summarise by emphasising the following points. First, only a small number of children in the UK have evidence of transfusion transmitted HTLV III, nearly all older, and nearly all severely affected haemophiliacs. Secondly, it seems only a small proportion (as yet unknown) of these infected children will develop frank immune deficiency, and even if they do they will simply become more of a risk to themselves, not others. Thirdly, although the virus is known to be present in blood, semen, saliva, and tears, disease transmission has not yet been reliably documented from saliva or tears, or from domestic or social contact. Finally, the incidence (as opposed to the prevalence) of transfusion transmitted HTLV III infection should now be nil. If the American experience is anything to go by, peri- natally transmitted disease will command the paediatrician's attention next.

\section{References}

1 Centers for Disease Control. Education and foster care of children infected with human T-lymphotropic virus type III/lymphadenopathy associated virus. Morbidity and Mortality Weekly Report 1985;34:417-21. (CSC, Atlanta, GA, 30333 USA).

2 Alter HJ, Eichberg JW, Masur H, et al. Transmission of HTLV III infection from human plasma to chimpanzees: an animal model for AIDS. Science 1984;226:549-52.

${ }^{3}$ Jones P, Hamilton PJ, Bird G, et al. Aids and haemophilia, morbidity and mortality in a well defined population. $\mathrm{Br} \mathrm{Med} \mathrm{J}$ 1985;291:695-9.

4 Lawrence DN, Jason JM, Bouhasin JD, et al. HTLV III/LAV antibody status of spouses and houschold contacts assisting in home infusion of hemophilia patients. Blood 1985;66:703-5.

5 Department of Health and Social Security. Acquired Immune Deficiency Syndrome AIDS. General information for doctors. DHSS CMO(85) 7. London: DHSS, 1985.

John S Lilleyman, Department of Haematology, The Children's Hospital, Western Bank, Sheffield S10 $2 \mathrm{TH}$ 